\title{
Financial Education and Timely Decision Support: Lessons from Junior Achievement
}

\author{
By Bruce Ian Carlin and David T. Robinson *
}

Financial literacy is defined as "the ability of people to make financial decisions in their own best short- and long-term interests" (Mandell, 2008). Unfortunately, this skill is in short supply, which may erode both personal and aggregate welfare (e.g., Lusardi and Mitchell, 2007). To date, three main avenues of research have been proposed to address this scarcity: (1) directly improving education (e.g., Bernheim, Garrett, and Maki, 2001); (2) improving access to timely decision support (Lynch, 2009); or (3) implementing judicious default options to limit the harm that people can do by not making an informed choice (Thaler and Sunstein, 2003).

The primary goal of this paper is to study the interaction between the first two approaches described above. Namely, we explore how the uptake of timely decision support is impacted by previous exposure to financial education.

To study this problem, we exploit the peculiar features of a training program developed by Junior Achievement. Our subjects are 2,357 Los Angeles students aged 13-19 years old who participated in a simulated consumer finance experience at the Junior Achievement Finance Park of Southern California during the 2008-2009 academic year. The Finance Park is a sim-

\footnotetext{
* Carlin: University of California at Los Angeles, NBER, bruce.carlin@anderson.ucla.edu. Robinson: Duke University, NBER, davidr@duke.edu. The authors would like to thank Viral Acharya, Doug Bernheim, Annamaria Lusardi, John Lynch, Adair Morse, and seminar participants at Vanderbilt University, Georgetown University, Duke University, and the 2010 Fall NBER Corporate Finance meeting for helpful comments and feedback. The authors would also like to thank Junior Achievement of Southern California for helpful discussions and guidance throughout the project. This work was conducted in compliance with IRB human subject guidelines and was approved by the IRBs at Duke and UCLA. Dan Blanchette provided excellent research assistance. Any errors are the authors' responsibility.
}

ulated consumer finance experience where students get a hands-on experience in personal budgeting. During the Finance Park simulation, students are randomly assigned a fictitious identity: for example, an eighthgrader might be asked to play the role of a single mother of two children. Their role-play identities include their age, employment, marital status, number of dependents, personal income, and taxes. The demographic characteristics of the fictional characters resembles that of the lowerincome neighborhoods where most of these students reside. For example, the character's gross annual income ranged from $\$ 20,000$ to $\$ 65,000$; median household income in Los Angeles in 2008 was $\$ 55,000$, but in the Compton neighborhood, the number was around $\$ 29,000$ in 2000 .

Participants begin by calculating their Net Monthly Income - their monthly takehome income net of taxes, Medicare, and Social Security contributions. Following this, students are asked to create a personal budget, which includes housing choices, health insurance, credit management, recreation, investment in continuing education, charity, cell phone plan, and home improvement. Volunteers at the park provide limited guidance to assist students in the task. After their budget is created, they go from kiosk to kiosk in the park to carry out the transactions they have budgeted. Details regarding the 17 kiosks in the park may be found in Carlin and Robinson (2009).

During the simulation, each student's goal is to create a balanced budget that reflects their preferences but also meets the needs of their fictional household situation. The data that we used in our analysis were the completed budget review statements that reflected the choices the students made while engaged in the role play. 


\section{Does financial literacy training affect behavior?}

One key to our identification strategy rests on the fact that some of the students received Junior Achievement-sponsored financial literacy training at their school before going to the finance park, and some did not. Students who were trained received 19 hours of instruction focusing on financial institutions, taxes, credit, and personal budgeting. In the curriculum, students receive three primary messages: 1 ) be wary of the costs of credit; 2) plan for the future; 3 ) take future costs into account when maximizing wealth today. Students participated in many concrete exercises that solidified these ideas.

Participation in the training program prior to attending the park was not mandatory. On balance, schools that opted out of the training program came from wealthier socio-economic backgrounds. Nevertheless, two schools sent both trained and untrained students to the park. We therefore use school fixed effects to identify educationbased differences in park budgeting decisions using the variation within these two schools. A total of 393 students attended the schools that sent both trained and untrained students.

In addition, a small set of students who went through the park twice, once before receiving the curriculum, and again about six weeks later after they received the curriculum. This second group allows us to check the magnitude of the treatment effect holding constant subject-specific demographic variation. The scope for learning from repetition in this group is muted by the fact that their fictitious identities were different each time.

Financial literacy training affected the students' choices in the park. For example, comparing the choices of students who went through the park twice, before and after the education, their savings rates were four times higher after the education, they paid off their debt faster, and spent considerably less on entertainment and dining out. All of these differences were statistically significant at the $5 \%$ level and were economically significant.

In general, students who received classroom financial literacy training made a range of choices that were consistent with delaying immediate gratification to increase overall wealth. The data indicate that students who received classroom training internalized the training program's messages of save more today, use credit sparingly, and plan for the future.

\section{Identifying the Interaction of Education and Decision Support}

A peculiar feature of the Park experience allows us to exploit variation in the degree and nature of decision support that respondents received. As part of the budget process, students were allocated mandatory home improvement expenditure of random size, and were asked to choose how they would amortize the payments associated with this budget item. The annual interest rate for these loans was approximately $21 \%$. The students could choose to make lower monthly payments, but by doing so they face higher interest costs over the life of the credit plan. Or they could choose to make larger payments, leaving them less money each month, but saving money over the life cycle of the credit plan. Park volunteers assisting in this step gave explicit guidance to the students, encouraging them to amortize their loans more quickly to avoid higher life-time interest costs.

At the health insurance kiosk, students face a similarly structured economic tradeoff, but without access to decision support. Students in the park were presented with a range of health insurance options, with increasing degrees of coverage corresponding to higher levels of monthly premia. Six plans were available: three with low premia and three with higher premia. The low premia plans all required the policy holder to pay a percentage of the total bill as a co-pay if health care is needed (e.g., a 15\% copay). The higher premia plans offered fixed-rate copays (e.g., a $\$ 15$ co-pay). In contrast to the home improvement kiosk, attendants at the health insurance kiosk did not advocate 
for one package or another, but instead simply explained concepts such as co-pays and premia.

To be sure, there are important differences in the types of decisions students are asked to make at these kiosks. The choices vary in terms of where they sit in a student's locus of control (ample research in psychology indicates that people understate the probabilities of bad outcomes when they think they can exert influence over those outcomes). They also have important risk differences: in the case of home improvement, there was no uncertainty surrounding future payments. In the case of health insurance, students were exposing themselves to potential income volatility by adopting percentage co-payment plans.

Nevertheless, the basic economic tradeoff faced at the two kiosks is similar in structure: both involve paying extra today to avoid paying more in the future. The choice is especially interesting in the context of the training students receive because it requires the student to hold two conflicting ideas in tension: on the one hand, the curriculum encourages students to spend less out of pocket each period; on the other hand, the curriculum encourages students to plan for the future.

The key difference in the two kiosks is the nature of decision support that was offered. At the home improvement kiosk, attendants actively prescribed one type of choice over another, whereas at the health insurance kiosk, they did not. This difference in access to decision support across the two kiosks is the second element of our identification strategy.

\section{Are Education and Timely Decision Support Complements or Substitutes?}

Panel A of Table 1 presents the results regarding home improvement in two ways. In the first two columns, the dependent variable is the log of the ratio of interest cost to total credit package size. The second two columns report regressions of log ratio of monthly payment to total credit plan size. All columns include school fixed ef- fects. Columns (1) and (3) include the natural log of income, while columns (2) and (4) replace log income with fixed effects for the ten income categories to allow for income to enter non-parametrically in the estimation. The fictional character's family structure and age are also included as controls, but are suppressed for brevity.

The effect of financial literacy training on the amortization of the home improvement plan is pronounced. Focusing on the first two columns, we see that the financial literacy exposure reduced the interest payments by about $11 \%$ of the total credit plan size. Columns (3) and (4) express the same finding in a complementary manner by showing that the finance training raised the monthly payout on the credit plan by about $8 \%$. (The p-values reported in parentheses below point estimates indicate that these effects are significant at the $1 \%$ level.)

As Panel A of Table 1 indicates, there was a significant interaction between prior exposure to financial literacy training and the presentation of timely advice about financial management. Attendants in the park frequently reminded students to consider paying off their debt earlier. However, even though the students who did not receive financial literacy training prior to the park experience heard the same advice, many did not take it. One interpretation is that the prior literacy training primes people to act on advice, or that the advice itself recalls past training that people have received.

The results regarding health insurance choice are presented in Panel B of Table 1. The first two columns examine whether someone was "under-insured". In our setting, this simply means that the respondent's character had a family (i.e., was married and/or had children) but only had individual insurance. Given the complexity of the overall budgeting problem that the students faced at the park, this variable measures task comprehension and effective budget preparation more than it measures attitudes toward risk. We determined this by comparing the character's family size to the reported cost of the plan they picked to see if they chose a policy that only covered a single person when their profile character 


\begin{tabular}{|c|c|c|c|c|c|c|c|c|}
\hline \multirow[b]{3}{*}{$\beta$} & \multicolumn{4}{|c|}{$\begin{array}{c}\text { Panel A: } \\
\text { Home Improvement Kiosk }\end{array}$} & \multicolumn{4}{|c|}{$\begin{array}{c}\text { Panel B: } \\
\text { Health Insurance Kiosk }\end{array}$} \\
\hline & \multicolumn{2}{|c|}{ Interest: } & \multicolumn{2}{|c|}{ Amortization: } & \multicolumn{2}{|c|}{ Underinsured: } & \multicolumn{2}{|c|}{ Flat-fee Co-pay: } \\
\hline & $(1)$ & $(2)$ & $(3)$ & $(4)$ & $(1)$ & $(2)$ & $(3)$ & $(4)$ \\
\hline $\begin{array}{l}\text { Curriculum } \\
\text { p-value }\end{array}$ & $\begin{array}{l}-0.110 \\
(0.001)\end{array}$ & $\begin{array}{l}-0.114 \\
(0.004)\end{array}$ & $\begin{array}{c}0.080 \\
(0.001)\end{array}$ & $\begin{array}{c}0.085 \\
(0.003)\end{array}$ & $\begin{array}{l}-0.033 \\
(0.003)\end{array}$ & $\begin{array}{l}-0.029 \\
(0.002)\end{array}$ & $\begin{array}{l}-0.161 \\
(0.005)\end{array}$ & $\begin{array}{l}-0.187 \\
(0.007)\end{array}$ \\
\hline
\end{tabular}

was married or had children. From the profile characteristics, it is clear that this occurred most often among people who were married without children. The presence of children made this much less likely. One reasonable explanation here is that the respondent assumed that their profile character's fictitious spouse had their own insurance somewhere else.

In the first two columns, we see that students who received financial literacy training were significantly less likely to inappropriately choose a lower cost plan that did not provide adequate coverage for their family. Therefore, they behaved as if they possessed a better understanding of the overall planning task faced at the health insurance kiosk.

The second two columns examine a dependent variable that is a dummy for whether the respondent chose a more expensive plan that offered flat-fee copayments. This choice is analogous to choosing higher monthly payments on the home improvement loan schedule so as to minimize lifetime costs, because the choice of a higher premium implies higher out of pocket costs today but lower expected health care payments in the future. The results are striking. Students with financial literacy exposure were much less likely to choose these plans. In doing so, they economized on monthly premia, but faced potentially higher out-of-pocket costs, and indeed, potentially more volatile income.

Comparing the results in Panels A and $\mathrm{B}$ allows us to explore the interaction between decision support and financial literacy. In Panel A, when students receive deci- sion support in the form of a nudge, trained students act on the information while untrained do not. In Panel B, when students received decision support that merely clarifies terminology without offering prescriptive advice, trained students fall back on heuristics (economize on costs, etc.) that are ill-suited to the task at hand.

This finding implies that financial education policies should not be abandoned in favor of decision support mechanisms, they should be pursued alongside the implementation of decision support mechanisms. Financial literacy and decision support are complements, not substitutes.

\section{Conclusion}

There are three central messages that emerge from our analysis. First, financial literacy can indeed be taught, but with important limitations. Trained students in many cases adopted the decision-making that the program stressed, but often had difficulty extrapolating the underlying principles to new settings. The second lesson is that education may have unintended consequences. The students who received the training even made some choices that were in some sense contrary to the spirit of the instruction they received. The third lesson, and perhaps the most important one, is that education and timely decision support are not distinct channels for improving consumer financial decision-making. They interact. Decision support was better utilized among the group that received financial literacy training. Timely decision support and financial literacy training are comple- 
ments, not substitutes. These findings suggest that prudent consumer finance policy would coordinate educational efforts with advice channels offered in the market to maximize people's ability to make good decisions.

\section{REFERENCES}

Bernheim, B. Douglas and Daniel M. Garrett and Dean Maki (2001), "Education and saving: The long-term effects of high school financial curriculum mandates," Journal of Public Economics 80, 435-465.

Carlin, Bruce I. and David T. Robinson (2009), "What Does Financial Literacy Training Teach Us?," NBER Working Paper 16271.

Lusardi, Annamaria, and Olivia S. Mitchell (2007). "Financial Literacy and Retirement Preparedness: Evidence and Implications for Financial Education." Business Economics, vol 42, 35-44.

Lynch, Jr., John G., (2009) "Information Remedies, Choice Architecture, and Plain Vanilla Financial Products," working paper, Russell Sage Foundation.

Mandell, Lewis (2008), "Teaching Young Dogs Old Tricks: The Effectiveness of Financial Literacy Intervention in PreHigh School Grades, chapter in Thomas A. Lucey and Kathleen S. Cooter (eds), Financial Literacy for Children and Youth Digitaltextbooks.biz.

Thaler, Richard H. and Cass R. Sunstein (2003), "Libertarian Paternalism." American Economic Review (Papers and Proceedings) 93(2) Fall: 175-179. 